\section{ANALISIS PENERAPAN METODE FULL COSTING DALAM PERHITUNGAN HARGA POKOK PRODUKSI UNTUK PENETAPAN HARGA JUAL}

\author{
Alviani Lestari, Siti Ita Rosita dan Tri Marlina \\ Program Studi Akuntansi, Sekolah Tinggi Ilmu Ekonomi Kesatuan \\ Bogor, Indonesia \\ Email:lemlit@stiekesatuan.ac.id
}

\section{Cost of \\ Production, Full \\ Costing, Cost of \\ Goods Sold}

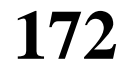

Submitted: JANUARI 2019

Accepted: APRIL 2019

Lemari Syukur Factory is a home industry that produces wardrobe cabinets. It determines selling price based estimation which is inappropriate. The main issue is that the company does not possess proper cost classification system in determining the cost of goods sold. This research is aimed to assist determining the cost of production as the basis for making up finished goods price using full costing method. This research includes quallitative analysis research. Data were collected through interviews and documentation and analyzed by qualitative analysis techniques.

The study resulted (1) for cost of goods sold calculation, the factory charged direct material costs of Rp. 325.000.000, direct labor cost of Rp. 211.200.000 and factory overhead cost of $R p$. 556,800,000. Total production cost to produce 2,196 units of cabinets in one year amounted to Rp. 1.093.000.000. The factory estimated cost of goods sold for each unit is of Rp. 497.723, and the selling price per cabinet unit is Rp. 500.000. (2) Using full costing method, the cost calculation consisted of direct material costs of Rp. 325.000.000, direct labor cost equal to Rp. 211.200.000, factory overhead fixed cost Rp. 12,042,250, and variable factory overhead cost Rp. Rp. 525.550.000. Thus, the cost of production was Rp. 1,073,792,250 for 2,196 units of cabinets. The cost of goods sold per cabinet unit is Rp. 488.976 and the selling price is Rp. 619.559. (3) The difference in cost of goods sold between full costing and the factory calculation is of $R p$ 8.747. While the difference between finished product price using full costing and the factory estimation is $R p 133.766$.

Keywords: Cost of Production, Full Costing, Cost of Goods Sold

\title{
PENDAHULUAN
}

Pentingnya melakukan perhitungan harga pokok produksi oleh perusahaan agar diketahui besarnya biaya produksi yang akan dikeluarkan saat akan memproduksi barang atau jasa. Tidak hanya perusahaan besar, para pelaku UMKM juga harus benarbenar dapat menghitung biaya produksi yang dikeluarkan untuk menentukan harga jual, sehingga tidak terjadi kesalahan yang dapat berpengaruh terhadap harga jual produknya.

Setiap pelaku usaha kecil dan menengah dituntut lebih efektif dan efisien dalam menjalankan usahanya sehingga memiliki daya saing dengan para kompetitornya. Salah satu cara yang dapat dilakukan adalah dengan menentukan besaran HPP dan harga jual yang tentu saja harus dengan harga yang wajar, tidak terlalu rendah dan juga tidak terlalu tinggi. Dampak yang terjadi bila salah menentukan harga jual adalah, apabila harga jual produk terlalu tinggi akan berdampak terhadap lemahnya daya saing perusahaan. Begitu pula sebaliknya, jika penentuan harga jual terlalu rendah maka dapat dipastikan laba yang didapat tidak akan maksimal.

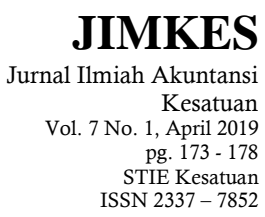


Cost of

Production, Full Costing, Cost of Goods Sold
Objek penelitian ini dilakukan di sebuah UMKM yang bergerak dibidang furniture, yaitu pembuatan lemari dengan nama usaha "Pabrik Lemari Syukur". Selama menjalankan usahanya, "Pabrik Lemari Syukur" telah berupaya untuk melakukan perhitungan harga pokok produksi secara sederhana tanpa mengelompokkan biayabiaya produksi untuk menghitung harga pokok produksinya.

\section{TINJAUAN PUSTAKA}

Untuk mendukung penelitian ini maka dibutuhkan beberapa landasan teori.

Menurut Mulyadi (2014:10) "Harga pokok produksi atau disebut harga pokok adalah pengorbanan sumber ekonomi yang diukur dalam satuan uang yang telah terjadi atau kemungkinan terjadi untuk memperoleh penghasilan”.

Menurut Mulyadi (2014:17-19) metode penentuan cost produksi adalah cara memperhitungkan unsur-unsur biaya ke dalam cost produksi. Dalam memperhitungkan unsur-unsur biaya ke dalam cost produksi, terdapat dua pendekatan yaitu full costing dan variabel costing.

Harga jual menurut Achmad Slamet dan Sumarli (2002:51) "adalah harga yang diperoleh dari penjumlahan biaya produksi total ditambah dengan mark up yang digunakan untuk menutup biaya overhead pabrik perusahaan".

Menurut Mulyadi (2009:34) ada tiga konsep yang dapat digunakan untuk menentukan harga jual, diantaranya:

1. Konsep Biaya Total

Berdasarkan konsep ini, harga jual ditentukan dari biaya total yaitu penjumlahan dari biaya produksi, biaya pemasaran, biaya administrasi umum, dan jumlah laba yang diinginkan oleh perusahaan.

2. Konsep Biaya Produk

Berdasarkan konsep biaya produk, harga jual ditentukan dari biaya produksi ditambah dengan markup.

3. Konsep Biaya Variabel

Dalam konsep yang disebut dengan contribution approach ini, harga jual ditentukan dari biaya variabel (biaya produksi variabel, biaya pemasaran variabel dan biaya administrasi umum variabel) ditambah dengan markup.

\section{METODE PENELITIAN}

Penelitian ini menggunakan metode analisis kualitatif, dimana peneliti berusaha untuk menggambarkan secara jelas keadaan objek yang diteliti berdasarkan data yang dikumpulkan kemudian melakukan analisis atas objek penelitian tersebut.

\section{HASIL DAN PEMBAHASAN}

\section{Perhitungan Harga Pokok Produksi UMKM "Pabrik Lemari Syukur"}

Berikut ini akan disajikan Perhitungan harga pokok produksi per unit lemari yang selama ini dilakukan oleh Pabrik Lemari Syukur, sebagai berikut : 
Perhitungan Harga Pokok Produksi UMKM

Pabrik Lemari Syukur Tahun 2016

\begin{tabular}{|c|c|c|c|}
\hline Keterangan & $\begin{array}{l}\text { Rata-Rata } \\
\text { Kebutuhan } \\
\text { Per Tahun }\end{array}$ & $\begin{array}{c}\text { Harga } \\
\text { (Rp) / } \\
\text { Unit } \\
\end{array}$ & Total (Rp) \\
\hline \multicolumn{4}{|l|}{ Biaya Bahan Baku Langsung } \\
\hline Partikel Board (PB) & $\begin{array}{l}2.600 \\
\text { Lembar }\end{array}$ & 75.000 & 234.000 .000 \\
\hline Kayu MDF & $\begin{array}{c}2.600 \\
\text { Lembar }\end{array}$ & 35.000 & 91.000 .000 \\
\hline $\begin{array}{l}\text { Jumlah Biaya Bahan Baku } \\
\text { Langsung }\end{array}$ & & & 325.000 .000 \\
\hline \multicolumn{4}{|l|}{ Biaya Tenaga Kerja Langsung } \\
\hline $\begin{array}{lcc}\text { Tenaga Kerja } & 8 & \text { orang } \\
@ \text { Rp. 2.200.000 } & & \\
\end{array}$ & $\begin{array}{l}8 \text { Orang x } 12 \\
\text { Bulan }\end{array}$ & $\begin{array}{c}2.200 \\
000\end{array}$ & 211.200 .000 \\
\hline \multicolumn{4}{|l|}{ Biaya Overhead Pabrik } \\
\hline Lem Presto (Kayu) & $1.900 \mathrm{Kg}$ & 10.000 & 19.000 .000 \\
\hline Lem Kuning & $280 \mathrm{Kg}$ & 35.000 & 9.800 .000 \\
\hline Lapisan Finish Foil & 18.000 Meter & 5.000 & 90.000 .000 \\
\hline Lapisan PVC & 18.000 Meter & 10.000 & 180.000 .000 \\
\hline Eazing / Vynil & 65.000 Meter & 1.200 & 78.000 .000 \\
\hline Aksesoris & 120.000 .000 & & 120.000 .000 \\
\hline Biaya Angkut & & & 60.000 .000 \\
\hline $\begin{array}{l}\text { Jumlah Biaya Overhead } \\
\text { Pabrik }\end{array}$ & & & 556.800 .000 \\
\hline Total Biaya & & & 1.093 .000 .000 \\
\hline Jumlah Produksi & & & 2.196 \\
\hline $\begin{array}{l}\text { Rata-Rata Harga Pokok } \\
\text { Produksi Per lemari }\end{array}$ & & & $497.723 *$ \\
\hline
\end{tabular}

*) Pembulatan

\section{Perhitungan Harga Pokok Produksi Metode Full Costing}

Full Costing merupakan metode penentuan biaya produksi dengan memperhitungkan unsur-unsur biaya produksi ke dalam biaya produksi, yang terdiri dari biaya bahan baku langsung, biaya tenaga kerja langsung, dan biaya overhead pabrik, baik variabel maupun tetap. Berikut ini ditampilkan biaya produksi "Pabrik Lemari Syukur" dengan menggunakan metode full costing :

Perhitungan Harga Pokok Produksi UMKM Pabrik Lemari Syukur dengan Metode Full Costing Tahun 2016

\begin{tabular}{|c|l|r|}
\hline No & \multicolumn{1}{|c|}{ Keterangan } & \multicolumn{1}{c|}{ Total Biaya (Rp) } \\
\hline 1 & Bahan Baku Langsung & 325.000 .000 \\
\hline 2 & Tenaga Kerja Langsung & 211.200 .000 \\
\hline 3 & Biaya Overhead Pabrik Tetap & 12.042 .250 \\
\hline 4 & Biaya Overhead Pabrik Variabel & 525.550 .000 \\
\hline 5 & Harga Pokok Produksi (Per Tahun 2016) & 1.073 .792 .250 \\
\hline 6 & Jumlah Produksi (Unit) & 2.196 \\
\hline 7 & Rata-Rata Harga Pokok Produksi Per Unit Lemari & $488.976^{*}$ \\
\hline
\end{tabular}


Cost of

Production, Full

Costing, Cost of

Goods Sold

$\underline{175}$

Analisis Perbandingan Harga Pokok Produksi antara Menurut UMKM dengan Metode Full Costing

Berikut disajikan perbandingan perhitungan harga pokok produksi "Pabrik Lemari Syukur" dengan perhitungan harga pokok produksi metode full costing :

Perbandingan Harga Pokok Produksi Menurut Metode UMKM dengan Metode Full Costing (Rupiah) Tahun 2016

\begin{tabular}{|c|c|c|c|}
\hline \multirow{2}{*}{ Jenis } & \multicolumn{2}{|c|}{ Harga Pokok Produksi/Unit } & \multirow{2}{*}{ Selisih } \\
\cline { 2 - 3 } & Metode UMKM & Metode Full Costing & \\
\hline Lemari 2 Pintu & 497.723 & 488.976 & 8.747 \\
\hline
\end{tabular}

Tabel di atas dapat menjelaskan bahwa perhitungan dengan menggunakan metode full costing ternyata menghasilkan harga pokok produksi yang lebih rendah. Hal ini disebabkan "Pabrik Lemari Syukur" selama ini membebankan biaya yang bukan sebagai unsur biaya overhead pabrik ke dalam perhitungannya. Walaupun perhitungan harga pokok produksi dengan metode full costing menghasilkan harga pokok produksi yang lebih rendah dari pada metode UMKM, tetapi perhitungan harga pokok produksi dengan metode full costing telah mencerminkan sumber daya yang digunakan dalam proses produksi, dimana perhitungan tersebut mencatat biaya produksi yang benar-benar terjadi pada setiap proses produksi.

Ketidaktepatan dalam pembebanan biaya overhead pabrik yang dilakukan membuat perhitungan HPP kurang tepat karena tidak mencerminkan konsumsi sumber daya secara lengkap dan akurat dalam proses produksinya. Harga pokok produksi yang lebih besar pada metode UMKM disebabkan oleh pembebanan biaya angkut dengan jumlah yang cukup besar.

Sedangkan dalam metode full costing biaya angkut tidak dimasukkan ke dalam perhitungan harga pokok produksi melainkan digunakan untuk menggunakan harga pokok penjualan. Meskipun metode full costing menghasilkan harga pokok yang lebih rendah namun unsur perhitungan biayanya lebih tepat karena menghitung semua unsur biaya-biaya dalam proses produksi seperti penyusutan mesin dan kendaraan, biaya listrik, serta biaya amplas kayu karena dalam metode full costing setiap aktibitas yang berhubungan dengan proses produksi dimasukkan dalam perhitungan harga pokok produksi.

\section{Perhitungan Harga Pokok Penjualan untuk Menentukan Harga Jual}

Pabrik Lemari Syukur dalam menentukan harga jual perunit lemari hanya berdasarkan perkiraan saja yaitu sebesar Rp. 500.000,-. Dengan Penentuan harga tersebut UMKM sudah memperoleh laba dan menutupi semua biaya-biaya yang dikeluarkan untuk memproduksi lemari.

Berikut ditampilkan perhitungan harga pokok penjualan untuk menentukan harga jual dengan metode full costing :

Perhitungan Harga Pokok Penjualan Menggunakan Metode Full Costing Pada UMKM Pabrik Lemari Syukur Tahun 2016

\begin{tabular}{|c|l|r|}
\hline No & \multicolumn{1}{|c|}{ Keterangan } & \multicolumn{1}{c|}{ Total Biaya (Rp) } \\
\hline 1 & Harga Pokok Produksi & 1.073 .792 .250 \\
\hline 2 & Biaya Pemasaran (Beban Angkut) & 60.000 .000 \\
\hline 3 & Jumlah Biaya & 1.133 .792 .250 \\
\hline 4 & Jumlah Produksi (Unit) & 2.196 \\
\hline 5 & Biaya Per Unit Lemari & $516.300^{*}$ \\
\hline
\end{tabular}


Berdasarkan Perhitungan harga pokok penjualan dengan metode full costing di atas didapat harga pokok penjualan per unit lemari sebesar Rp. 516.300 yang diperoleh dari biaya produksi (harga pokok produksi) ditambah biaya non produksi (biaya angkut) dibagi dengan jumlah unit produksi dalam 1 tahun yaitu 2.196 unit. Perhitungan tersebut menjadi dasar penentuan harga jual lemari per unit, sehingga harga jual tidak di bawah harga tersebut.

Laba yang ditetapkan dari produksi lemari adalah sebesar $20 \%$ dari harga pokok penjualan. Sehingga untuk menentukan harga jual lemari per unit dapat dirumuskan, sebagai berikut :

Harga Jual $=$ B. Produksi + B. Pemasaran + B. Adm. Umum + Markup

Jumlah Produksi

$$
=1.073 .792 .250+60.000 .000+0+\{(1.073 .792 .250+60.000 .000) \times 20 \%\}
$$

$$
=\underline{1.133 .792 .250+226.758 .450}
$$

2.196

$$
\begin{aligned}
& =\frac{1.360 .550 .700}{2.196} \\
& =619.558,60=619.559 \text { (Pembulatan) }
\end{aligned}
$$

\section{Analisis Perbandingan Harga Jual Antara Perhitungan UMKM dengan Metode

\begin{tabular}{|c|c|c|c|}
\hline \multicolumn{4}{|c|}{$\begin{array}{c}\text { Perbandingan Harga Jual Menurut Metode UMKM } \\
\text { dengan Metode Full Costing (Rupiah) Tahun } 2016\end{array}$} \\
\hline \multicolumn{4}{|c|}{ Harga Jual/Unit } \\
\hline Jenis & $\begin{array}{l}\text { Metode } \\
\text { UMKM }\end{array}$ & $\begin{array}{l}\text { Metode Full } \\
\text { Costing }\end{array}$ & Selisih \\
\hline Lemari 2 Pintu & 500.000 & 619.559 & 119.559 \\
\hline
\end{tabular} Full Costing}

Untuk mendapatkan hasil perbandingan antara penentuan harga jual dengan metode perhitungan UMKM dengan metode perhitungan full costing dapat disajikan sebagaimana tabel di bawah ini:

Berdasarkan tabel di atas maka dapat dianalisis bahwa perhitungan harga jual dengan metode full costing menghasilkan harga jual yang lebih besar bila dibandingan dengan penentuan harga jual menurut UMKM. Hal tersebut dikarenakan dalam metode full costing, seluruh unsur biaya dimasukkan dalam perhitungan harga pokok penjualan baik biaya produksi maupun non produksi, selain itu metode full costing juga lebih mencerminkan persentase keuntungan yang diinginkan oleh UMKM tidak hanya berdasarkan perkiraan saja.

Saat ini UMKM dengan menentukan harga jual sebesar Rp.500.000,- per unit lemari memang sudah memperoleh laba, namun dengan harga tersebut tidak mencerminkan laba yang diharapkan oleh UMKM, yaitu persentase laba sebesar $20 \%$ dari harga pokok penjualan. Perhitungan dan penetapan harga jual jika hanya berdasarkan perkiraan saja dapat menyebabkan terjadinya kesalahan dalam menetapkan harga jual, yang dimana kesalahan tersebut akan berdampak fatal bagi kelangsungan usaha yakni menimbulkan kerugian.

Production, Full

Costing, Cost of

Goods Sold 
Cost of

Production, Full

Costing, Cost of

Goods Sold

$\underline{177}$

\section{SIMPULAN}

Beberapa simpulan yang dapat diuraikan dari penelitian ini adalah :

1. Selama ini UMKM "Pabrik Lemari Sukur" menggunakan metode perhitungan harga pokok produksi secara sederhana tanpa memperhatikan kaidah akuntansi biaya. Dalam perhitungan harga pokok produksi yang dilakukan oleh UMKM tidak memasukan semua unsur biaya, khususnya biaya overhead pabrik, yang mengakibatkan harga pokok produksi yang diperoleh tidak sesuai dengan kaidah perhitungan harga pokok produksi berdasarkan pencatatan akuntansi biaya. Dengan perhitungan harga pokok produksi menggunakan metode full costing diperoleh harga pokok produksi yang lebih rendah. Hal ini disebabkan karena pencatatan biaya produksi yang tidak tepat, dimana sumber daya yang dilakukan dalam proses produksi tidak dimasukkan oleh UMKM sebagai dasar perhitungan harga pokok produksi.

2. Metode perhitungan harga pokok produksi "Pabrik Lemari Syukur" menghasilkan harga pokok produksi yang lebih besar dibandingkan metode full costing. Hal ini disebabkan oleh biaya overhead pabrik tidak dibebankan ke produk secara tepat sehingga harga pokok yang dihasilkan tidak mencerminkan pemakaian biaya overhead pabrik yang sesungguhnya. Selain itu, UMKM juga membebankan biaya angkut sebagai salah satu unsur dasar perhitungan harga pokok produksi. Sedangkan metode full costing memasukan biaya angkut sebagai dasar perhitungan harga pokok penjualan dan biaya overhead pabrik telah dibebankan sesuai dengan pemakaian biaya yang sesungguhnya.

3. Hasil perhitungan harga pokok produksi yang dilakukan oleh UMKM tidak mencerminkan laba yang diinginkan oleh UMKM sebesar $20 \%$.

4. Perhitungan harga jual menurut UMKM lebih rendah bila dibandingan dengan menggunakan metode full costing. Hal ini dapat menyebabkan kelangsungan usaha UMKM dapat terganggu jika perhitungan harga pokok penjualan yang dilakukan oleh UMKM tidak dicatat sesuai dengan kaidah akuntansi biaya.

\section{DAFTAR PUSTAKA}

Mulyadi. 2009. Akuntansi Biaya.Yogyakarta: STIE YPKPN.

Mulyadi. (2014). Akuntansi Biaya Edisi 5. Yogyakarta: Unit Penerbit Dan Percetakan Sekolah Tinggi Manajemen YKPN.

Peraturan Pemerintah No. 17 tahun 2013 tentang Pelaksanaan UU No. 20 tahun 2008 tentang Usaha Mikro, Kecil dan Menengah.

Slamet, A. \& Sumarli. (2002). Pengaruh Perkiraan Biaya Produksi dan Laba Yang Diinginkan Terhadap Harga Jual Pada Industri Kecil Genteng Pres. 